\title{
THE CONCEPT OF INDEX FOR THE ASSESSMENT OF REGULATIONS' SIGNIFICANCE (IARS) IN REGULATORY IMPACT EVALUATION*
}

\section{INTRODUCTION}

The economic analysis of law is a concept which makes it possible to conduct research on law with the methodology and tools applied in the economic sciences. It has become an essential area of interest in the new institutional economics and political economics. According to Charles K. Rowley, the economic analysis of law concerns the application of economics and quantitative methods in order to examine the forms, structures, processes, institutions and impacts of law. ${ }^{2}$ What is more, economics as a social science can complement the legal sciences with standards of a normative character, which not only make legal assessment possible, but also enable the efficiency of political activities to be assessed. ${ }^{3}$

The evolution of the concept of the economic analysis of law involved two major stages. The first one was initiated in the $1800 \mathrm{~s}^{4}$, and the second in the 1930s. ${ }^{5}$ However, intensive development in the economic analysis of law started as late as the 1980s. One of the reasons behind this trend was the establishment of the European Union and the introduction of the principle of the primacy of EU law over national law. However, we have been witnessing the development of another stage of the concept of the economic analysis of law, launched after 2008 , following the global financial crisis, which brought about a huge increase in the number of legal regulations (the so-called legislative inflation), particularly concerning the financial system.

The growing significance of the economic analysis of law embraces the whole of the legislative process, but it is of particular importance when con-

* Previous versions of this article were presented at the European Centre for Parliamentary Research and Documentation (ECPRD) seminar: Pre- and Post-legislative scrutiny in and beyond parliament, Dublin, Houses of the Oireachtas (Irish Parliament), November 2016 and the 34rd Annual Conference of European Association of Law and Economics, 13-15 September 2017, London.

${ }^{2}$ Rowley (1989): 125.

${ }^{3}$ Cooter, Ulen (2008): 3-6.

${ }^{4}$ More Pearson (1997).

${ }^{5}$ Posner (2003). 
ducting assessments of the impacts of a draft regulation (ex-ante), and assessments of the impacts of regulations already in force (ex-post).

Ex-post assessment, as opposed to ex-ante regulatory impact assessment, is an analysis carried out within a certain period of time following the entry into force of a given act and is aimed at verifying whether the goals and effects assumed in the draft act have been achieved or not. The conclusions derived from the results of the analysis ought to provide a basis for the decision on whether to maintain, change or withdraw the given legal act from legislation, and thus from the economy.

In recent years, ex-post regulatory impact assessment has become one of the increasingly common stages in the legislative procedure in a number of countries. The process of the practical implementation of ex-post regulatory impact assessment in certain countries has been sluggish but gradual. There are several reasons for this state of affairs.

One of them is the elements of the good governance concept, implemented in many countries (as well as in EU institutions), of which one of the pillars is good (or even smart ${ }^{6}$ ) regulations. The aim of this concept is, among other things, a systemic reduction or periodical verification of the number of the legal acts made. In this respect, good practice is recommended by the Organisation for Economic Co-operation and Development $(\mathrm{OECD})^{7}$ and the European Union. ${ }^{8}$

Another reason results from the need to assess the impacts of the implementation or modification of numerous legal regulations enacted to counteract the latest financial crisis. This process has been particularly intensive in EU Member States, which, apart from the legislative decisions of their own government, also had to launch the process of adapting domestic regulations to supranational (European) regulations. Hence, at present, a great number of new or altered legal acts require and will still require a systematic assessment of their impacts in the post-crisis environment.

A third reason why public authorities have developed an interest in ex-post regulatory impact assessment is the increasingly intensified pressure from various social groups which demand or themselves provide analyses aimed at indicating the low efficiency of the laws implemented and their adverse consequences for the business sector and the whole of society. In this context, it is worth highlighting the advantages of implementing the public governance principle in so many countries.

The data published in 2015 shows that out of all the OECD ${ }^{9}$ member countries as few as twenty conduct mandatory ex-post regulatory impact assessment, and only a few do so regularly. Among the researched states, assessments are conducted primarily in the case of regulations having 'sunsetting' clauses. ${ }^{10}$

\footnotetext{
${ }^{6} \mathrm{COM}(2010) 543$ final.

7 OECD (2012).

${ }^{8} \operatorname{COM}(2012) 746$ final.

9 OECD (2015): 130-131.

${ }^{10}$ A clause included in a regulation or similar piece of legislation that provides for an automatic repeal of an entire law or sections of a law once a specific date arrives.
} 
Most often, the extent to which the goal is achieved, and the occurrence of unplanned consequences, is subject to verification.

The ex-post regulatory impact assessment can be carried out with respect to the whole of the legislation process, by both the government (as the draft act originator), or parliament (which performs the scrutiny function). Additionally, such analyses can be commissioned by independent research institutes under public consultation.

One of the prerequisites for conducting an effective ex-post regulatory impact assessment is its impartiality and independence, but also its quality and usefulness in making practical decisions. Thus, ex-post assessment must not concern legal and procedural aspects exclusively. The entities that are subject to the given regulation, as well as its originators, must have interests in the economic (that is factual) effects resulting from the implementation of the given legal regulation. Thus, the conclusions from the assessment of the financial, economic, social or environmental impacts that the implementation of the given act produces ought to become an essential element of each legislative procedure.

In this article, the author presents the theoretical concept of the Index for the Assessment of Regulations' Significance (IARS), which serves as a standard and periodical tool applied in the parliamentary legislative procedure. The Index allows a quick and simple control of single draft acts (the assessment of their ex-ante effects), and of the whole procedure according to substantive criteria, but in the first place it ensures the impartial and independent selection of the regulations to be assessed ex-post.

\section{PARLIAMENTARY REGULATORY IMPACT ASSESSMENT}

Regulatory impact assessment (RIA) is an element of legislative procedure conducted primarily by the government, as the major originator of a given legal act. In contemporary legislative procedures, the RIA, the public hearing and broad public consultations are all significant tools for making law, which are, however, used to a varying extent. Formally, they are applied on both the European (the Commission and the European Parliament) and national levels.

Regulatory impact assessment remains a vital element of control over the validity of further proceeding with a regulation in parliament. In that regard, parliamentary services (offices) ought to provide deputies with analytical support, by conducting an independent and impartial assessment following the adopted rules and methodology. Such parliamentary control of both a draft act (the ex-ante assessment) and the already enacted law (the ex-post assessment) enables the parliament to effectively verify the legislative process (including the possibility of restraining the process).

The following diagram presents the traditionally applied scheme of the legislative procedure in parliaments. 


\section{Diagram 1}

The traditional legislative procedure in parliaments with the application of RIA

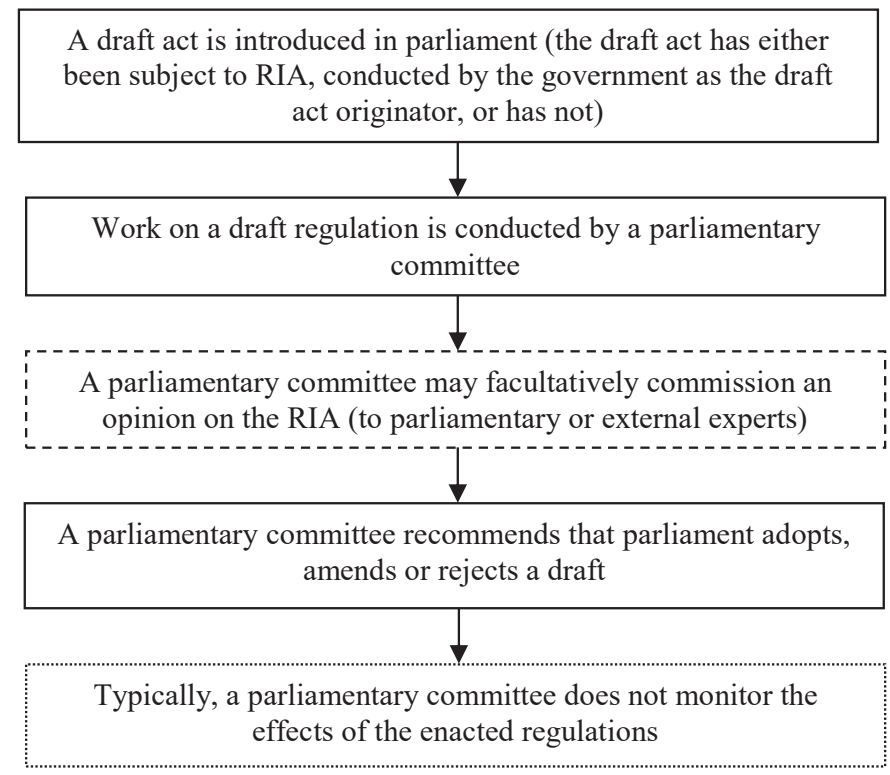

Source: author's own work.

In most cases, the legislative procedure in parliament is rather simplified. The first stage of work is undertaken in committees; then, the whole parliament becomes involved in the decision-making process. However, parliamentary committees use RIA instruments of the legislative procedure to a varying extent.

A survey carried out in 2016 by the European Parliament ${ }^{11}$ shows that out of the 28 parliaments of EU Member States, $52 \%$ of them do not conduct any analyses into RIA. Within the remaining 48\%, 6 parliaments conduct both exante and ex-post assessments, while the other 6 ex-post only. The parliaments that do conduct regulatory impact assessment are those of the following Member States: Austria, Belgium, Germany, Denmark, Finland, France, Greece, Italy, the Netherlands, Poland, Portugal and Sweden. Furthermore, ex-ante and ex-post RIA is also conducted in the EU Parliament.

Few parliaments have developed a relevant methodology for conducting an assessment. They include parliaments in the following countries: Austria, Germany, Denmark, the Netherlands, Sweden and Poland. The EU Parliament has different methodologies for each particular procedure.

It is also worth pointing out that $56 \%$ of the above-mentioned national parliaments publish the results of their analyses, and $83 \%$ also allow the use of external expert appraisals. Moreover, some parliaments establish special analytical units (bureaus) which also conduct RIAs (for example the Research

11 ECPRD (2016). 
Service in Finland, the Research Bureau in Poland). In that regard, the EU Parliament is the best example, as it has the following structures: Directorate for Impact Assessment and European Added Value in the Directorate-General for Parliamentary Research Services including the Ex-Ante Impact Assessment Unit and the Ex-Post Impact Assessment Unit.

\section{THE CONCEPT OF THE INDEX FOR THE ASSESSMENT OF REGULATIONS' SIGNIFICANCE}

The concept of the Index for the Assessment of Regulations' Significance is an element of the methodology developed by the Bureau of Research of the Sejm..$^{12}$ Under the regulations of the Constitution of the Republic of Poland (hereinafter the RP) of 1997, the legislative initiative is primarily in the hands of the government (the Council of Ministers). The other entities entitled to initiate new regulations or amendments of the binding laws include the President of the RP, deputies of the Sejm, and the Senate of the RP. Under legislative procedure, the Council of Ministers is obliged, by the provisions of the Public Finance Act and the Rules of Procedure of the Sejm, to attach a justification with each government draft act, which ought to include a justification of the necessity and purpose of the new act, indicating the differences between the existing and draft bills, submitting the results of the conducted consultations, and providing analysis of the findings with regard to the predicted social, economic, financial and legal implications of the new act. The Sejm of the RP (not the deputies themselves) performs the scrutiny function over government drafts (and not only the government drafts) in the ongoing legislative process, particularly at the stage of the validity control of the ex-ante regulatory impacts included in draft acts. Sejm committees (and deputies) receive substantive support in this respect from the Bureau of Research of the Chancellery of the Sejm (hereinafter the BR), which employs independent experts in a number of fields, such as legal, financial, economic, social and environmental.

The BR conducts legal, economic and social analyses concerning the bills to be enacted. We must add though that this procedure is not of a systematic character and it does not cover all the draft acts submitted to the Sejm in the legislative procedure. It concerns solely those drafts that are commissioned by Sejm committees or individual deputies, taking account of the limitations in the scope of analysis imposed by the committees. However, the Rules of Procedure of the Sejm of the RP enable the BR to perform a broader scope of tasks, including an independent ex-post regulatory impact assessment (RIA).

The study conducted by the BR in the years 2014-2015 resulted in the development of a preliminary procedure for ex-ante and ex-post regulatory impact assessment with regard to the scrutiny function performed by the Sejm. One of the elements of the above-mentioned procedure is the Index for the Assessment of Regulations' Significance (IARS) developed by the author of this article.

${ }^{12}$ BAS (2015). 
The Index for the Assessment of Regulations' Significance (IARS) is a mathematical formula developed on the basis of the data acquired from a detailed, legal and substantive quantitative (score) assessment of particular legal acts under the adopted criteria.

The Index can be widely used, and:

- it may serve to conduct a preliminary ex-ante RIA control with respect to draft acts submitted to the parliament;

- it may enable a statistical analysis of the whole legislative process in parliament over a selected period to be conducted, using substantive criteria;

- it may be a tool for making an impartial and independent selection of acts the ex-post regulation impacts of which are to be assessed.

Thus, the application of the IARS makes it possible for parliamentary committees to access some additional information which enables them to make decisions and perform their scrutiny function during the stage of processing a draft legal act and during the verification of its implementation effectiveness (Diagram 2).

\section{Diagram 2}

The legislative procedure in parliament using the IARS concept

A draft act is introduced in parliament (the draft act has either been subject to RIA, conducted by the government as the draft act originator, or not)

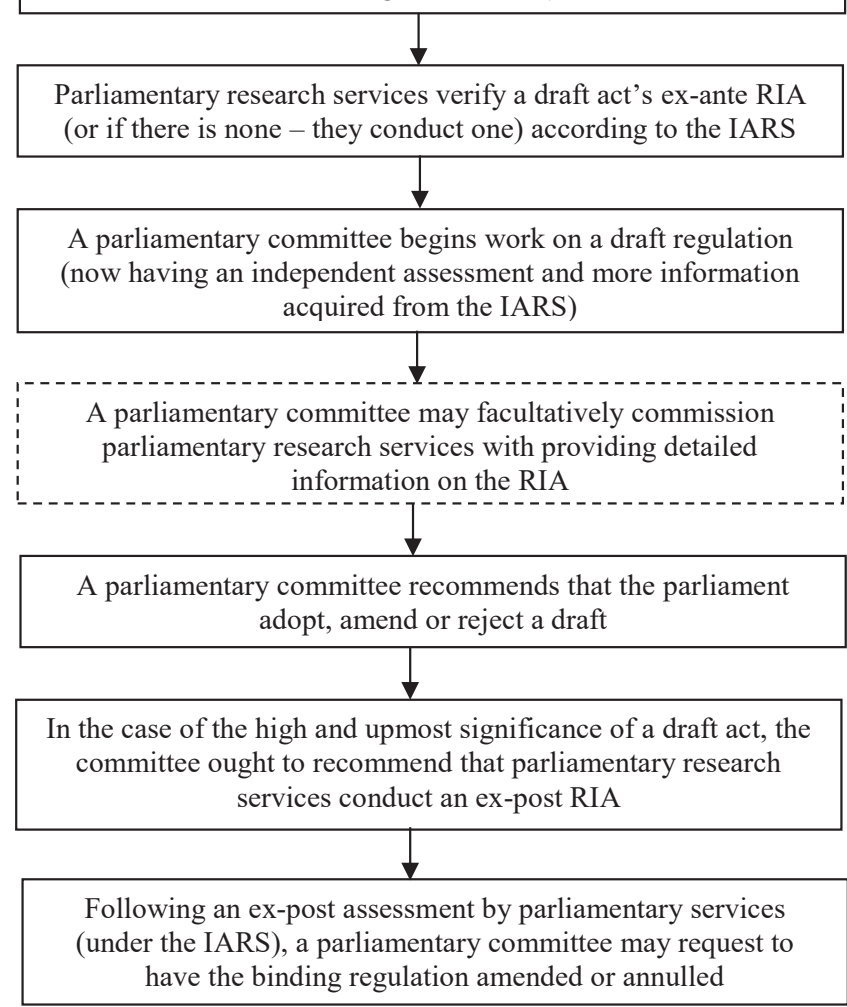

Source: author's own work. 
The construction of the IARS is based on the information that can be acquired by parliamentary services from draft acts, which are next subject to assessment according to the established overall and detailed criteria (see Table 1 - the overall criteria are provided in the second column). The criteria are then quantified according to the established significance scale and marked numerically using relevant weight functions.

Regulatory impact assessment is based on five criteria:

1) draft act originator,

2) the entity scope of the regulation - entities impacted by the regulation, target group,

3) the subject scope of the regulation - regulation impact areas,

4) the legal character of the regulation,

5) regulation impacts.

Table 1

The Index for the Assessment of Regulations Significance (IARS)

\begin{tabular}{|c|c|c|c|}
\hline $\begin{array}{c}\text { Assessment } \\
\text { criterion }\end{array}$ & Criterion characteristics & $\begin{array}{l}\text { Assessment } \\
\text { scale }\end{array}$ & Weight \\
\hline $\begin{array}{l}\text { Draft act } \\
\text { originator } \\
\text { abbr. DAO }\end{array}$ & $\begin{array}{l}\text { 1) Government draft act } \\
\text { 2) deputies' draft act } \\
\text { 3) Senate's draft act } \\
\text { 4) President's draft act } \\
\text { 5) citizens' initiative }\end{array}$ & $\begin{array}{l}2^{*} \\
1 \\
1 \\
1 \\
1 \\
\end{array}$ & 0.1 \\
\hline $\begin{array}{l}\text { The entity } \\
\text { scope of the } \\
\text { regulation } \\
\text { abbr. ESR }\end{array}$ & $\begin{array}{l}\text { 1) non-financial corporations } \\
\text { 2) financial corporations } \\
\text { 3) general government entities } \\
\text { 4) households } \\
\text { 5) non-profit institutions serving } \\
\text { households }\end{array}$ & $\begin{array}{l}1 \\
1 \\
1 \\
1 \\
1\end{array}$ & $\begin{array}{c}0.2 \\
\text { (0.04 for each } \\
\text { criterion) }\end{array}$ \\
\hline $\begin{array}{l}\text { The subject } \\
\text { scope of the } \\
\text { regulation }\end{array}$ & $\begin{array}{l}\text { 1) the efficiency and effectiveness } \\
\text { of the state (of the public finance } \\
\text { sector) } \\
\text { 2) entrepreneurship, competitiveness } \\
\text { and innovativeness of the economy } \\
\text { 3) the labour market } \\
\text { 4) regional development and cohesion } \\
\text { 5) the market and macroeconomic } \\
\text { environment and the foreign policy } \\
\text { 6) social issues } \\
\text { 7) the natural environment } \\
\text { 8) other areas }\end{array}$ & $\begin{array}{l}1 \\
1 \\
1 \\
1 \\
1 \\
1 \\
1 \\
1\end{array}$ & $\begin{array}{c}0.32 \\
\text { (0.04 for each } \\
\text { criterion) }\end{array}$ \\
\hline $\begin{array}{l}\text { The legal } \\
\text { character } \\
\text { of the } \\
\text { regulation } \\
\text { abbr. RLC }\end{array}$ & $\begin{array}{l}\text { 1) a new regulation in the given area } \\
\text { 2) a substantive change in an area } \\
\text { regulated already } \\
\text { 3) a change bringing order to an area } \\
\text { regulated already }\end{array}$ & $\begin{array}{l}3 \\
2 \\
1\end{array}$ & 0.1 \\
\hline
\end{tabular}




\begin{tabular}{|l|l|c|c|}
\hline Regulation & 1) economic impacts & 2 & \\
impacts & 2) social impacts & 2 & 0.28 \\
& 3) financial impacts & 2 & (0.04 for each \\
abbr. RI & 4) administration impacts & 1 & criterion) \\
& 5) environmental impacts & 1 & \\
& 6) legal impacts & 1 & \\
& 7) other impacts & 1 & \\
\hline
\end{tabular}

* for government drafts, scale 2 has been adopted due to the obligation to attach an RIA conducted by the government (it is not obligatory, however)

Source: author's own work.

The result of the analysis of the given legal act ultimately takes the form of a particular number, which should fall within the adopted range.

The IARS formula

$$
\begin{gathered}
I A R S=0.1 D A O+0.2(E S R 1+E S R 2+E S R 3+E S R 4+E S R 5) / 5+0.32 \\
(S S R 1+S S R 2+S S R 3+S S R 4+S S R 5+S S R 6+S S R 7+S S R 8) / 8+0.1 R L C+0.28 \\
(R I 1+R I 2+R I 3+R I 4+R I 5+R I 6+R I 7) / 7
\end{gathered}
$$

The IARS range: min. - 0.32 (least significant); max. - 1.42 (upmost significant); average -0.55

\section{AN EXEMPLARY APPLICATION OF THE IARS}

As mentioned above, one of the applications of the IARS is conducting analyses of the whole legislative process in parliament over a given period. Under the ex-ante RIA control, relevant services ought to verify the initial assumptions of act originators according to the established assessment criteria. This is made possible by an individual verification of each draft act that is subject to process in parliament under the IARS criteria. The final (score) result should also provide a basis for carrying out a preliminary assessment of a draft act's significance.

The final (numerical) result also provides a basis for a preliminary RIA. Thus, the standardization of the assessment criteria is a tool that enhances the expertise of parliamentary services in the given subject scope of a draft legal act.

Below, an example analysis of a legislative process of the Sejm of the $\mathrm{RP}$ based on the IARS is presented, covering the second half of 2012 . The analysis covered a total of 116 draft acts, excluding 'special' drafts, such as the budget draft act, budget-related draft acts, or ratification draft acts (Graphs 1-4). 


\section{Graphs 1-4}

An analysis of legal acts under the IARS

(the legislative procedure - the second half of 2012, the Sejm)

\section{Draft act originator}

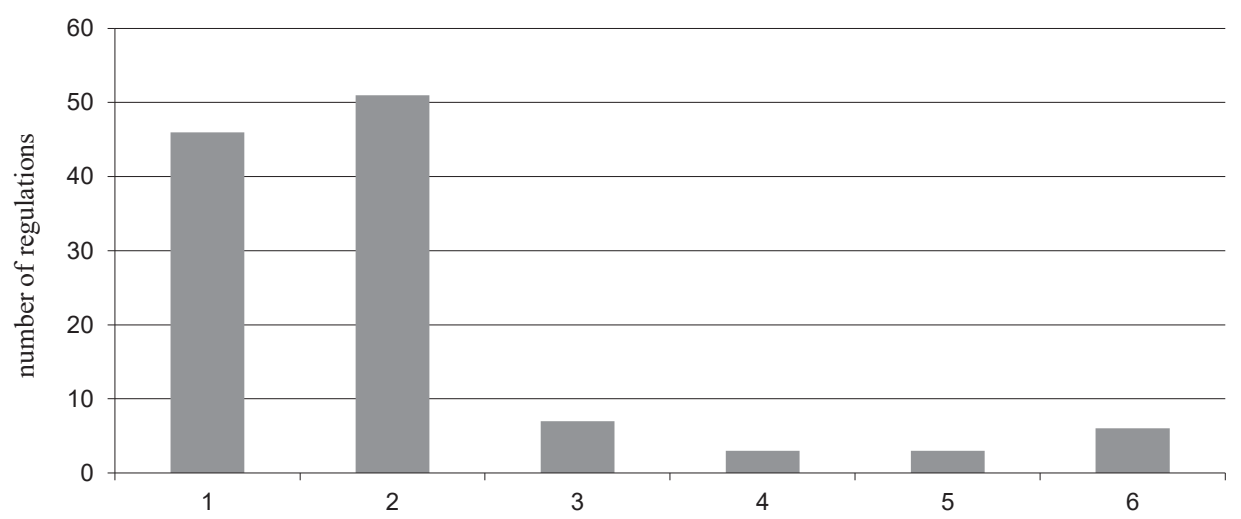

score in accordance with the IARS

1) Government draft act

2) deputies' draft act

3) Senate's draft act

4) President's draft act

5) citizens' initiative

The entity scope of the regulation

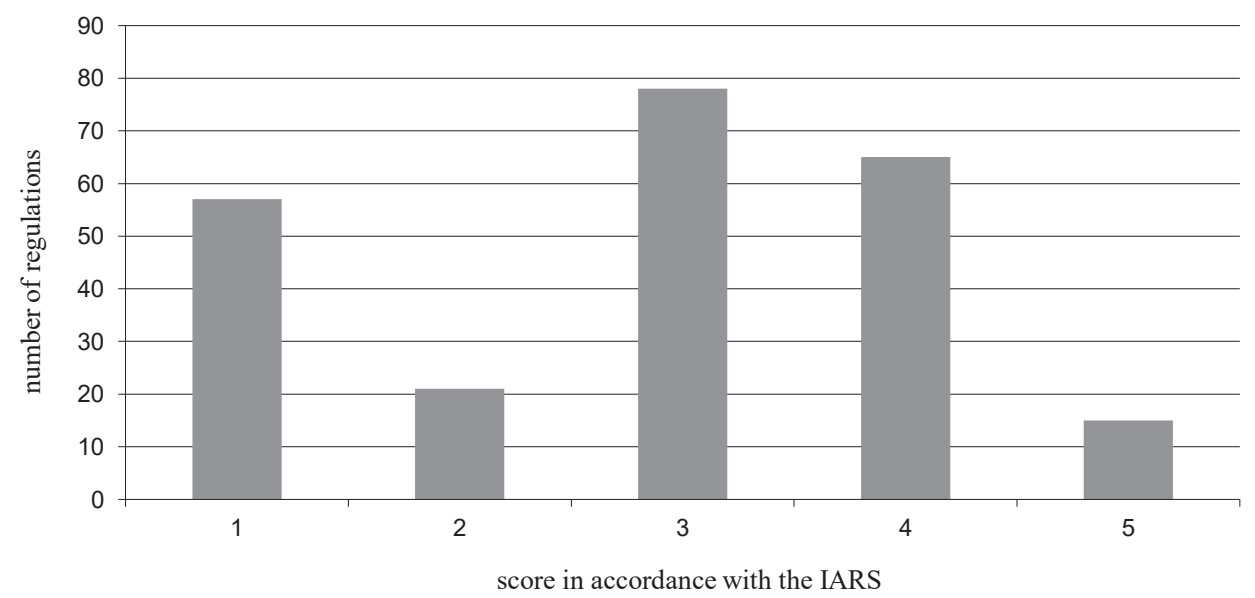

1) non-financial corporations

2) financial corporations

3) general government entities

4) households

5) non-profit institutions serving households 
The subject scope of the regulation

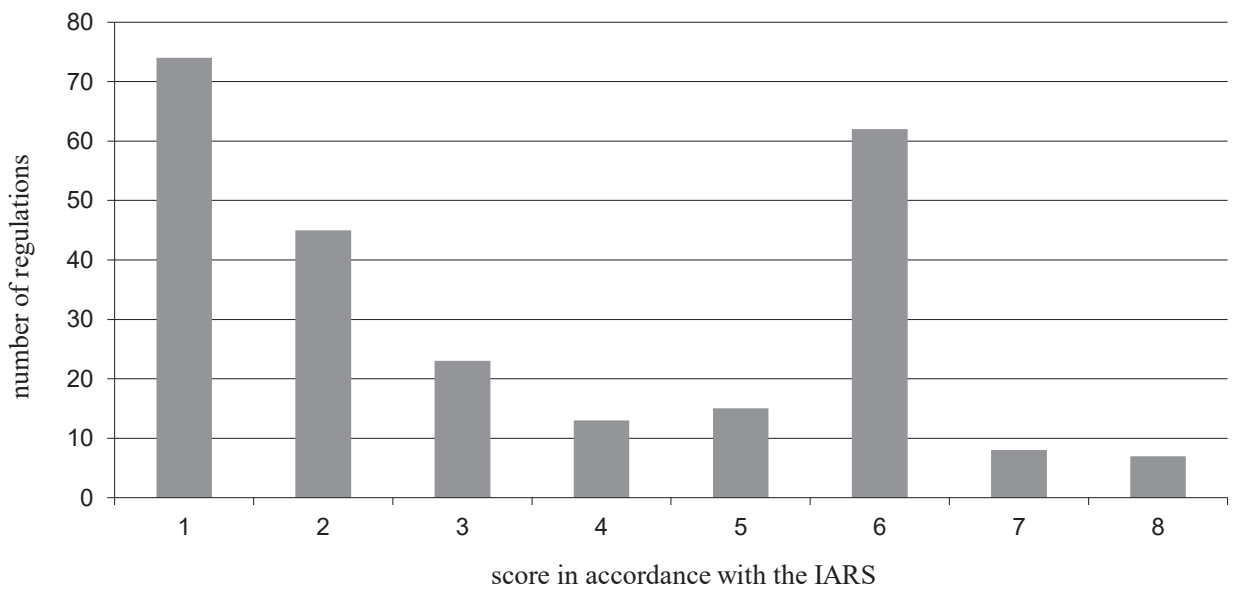

1) the efficiency and effectiveness of the state (of the public finance sector)

2) entrepreneurship, the competitiveness and innovativeness of the economy

3) the labour market

4) regional development and cohesion

5) internal economy (the market and macroeconomic environment) and foreign policy

6) social issues

7) the natural environment

8) other areas

\section{Regulation impacts}

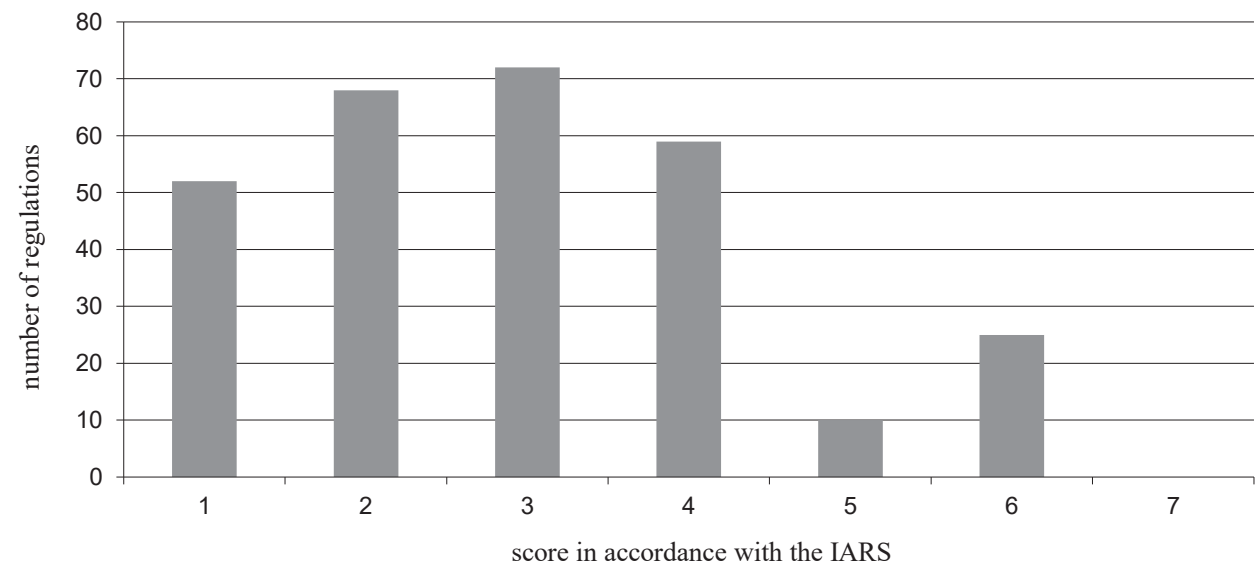
1) economic impacts
2) social impacts
3) financial impacts
4) administration impacts
5) environmental impacts
6) legal impacts
7) other impacts

Source: data based on drafts of acts submitted to the Sejm. 
Research findings show that over the period in question:

- more drafts were submitted by deputies than by the government;

- the biggest number of drafts concerned the general government, and the smallest amount concerned the public finance sector;

- most regulations (46) concerned only one group of entities (by the frequency criterion); 41 regulations covered two groups of entities;

- in the case of the regulations' impact area, most of them concerned the effectiveness and efficiency of the state (74), and social issues (62), with regulations usually covering two subject areas;

- most regulations were substantive amendments in previously regulated areas;

- the majority of drafts entailed financial implications, followed by those that entailed social implications, with most of the proposed regulations covering two types of implications simultaneously.

Another application of the IARS is to enable the impartial and independent selection of legal acts that will undergo an ex-post regulatory impact assessment. The selection can be made over a specific period, for example half a year, a year or two years. An additional criterion that must be included in terms of the already available IARS data is the information on whether the given legal act is still binding or not (that is over the assessment period). Relevant, too, will be the recommendation of a parliamentary committee, submitted during the exante procedure stage, on a given draft act, in the case of its enactment.

Thus, in the example below, all of the analyzed legal acts are sorted by the acquired IARS numerical result. As shown in the chart, in the second half of 2012 , the results of the Index for the legal acts processed then ranged between 0.42 and 1.2 (Graph 5).

\section{Graph 5}

Ranking legal acts according to the IARS result (the legislative procedure - the second half of 2012, the Sejm)

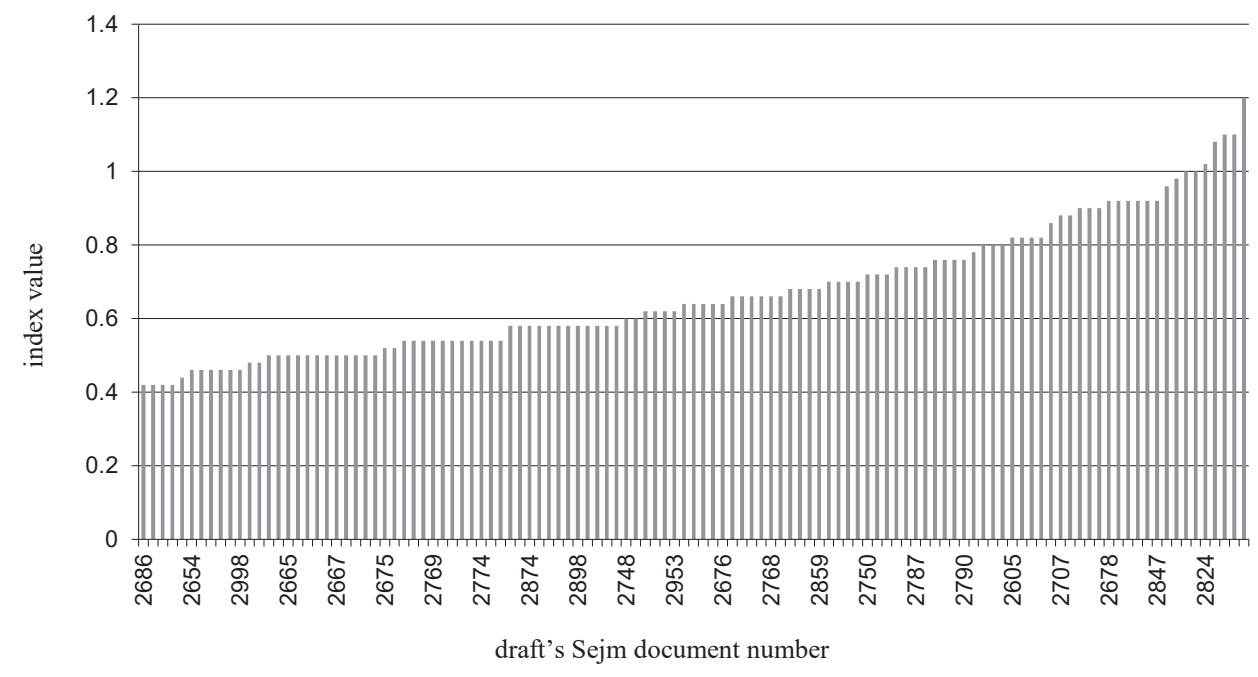

Source: data based on drafts of acts submitted to the Sejm. 
The IARS application methodology requires indicating what proportion of the most significant legal acts with the highest result will be taken into account when conducting an ex-post assessment (for example 5\%, 10\%, 20\%). Such a decision ought to depend not only on substantial prerequisites, but also on the staff and time capacity of the expert teams (including those performing external expert appraisals) that conduct the assessment.

Table 2

The results of the selection of legal acts within the ex-post RIA under the IARS

\begin{tabular}{|c|c|c|c|c|c|}
\hline $\begin{array}{l}\text { IAS } \\
\text { result }\end{array}$ & $\begin{array}{c}\text { Doc. } \\
\text { no. }\end{array}$ & $10 \%$ & $\begin{array}{l}\text { IARS } \\
\text { result }\end{array}$ & $\begin{array}{l}\text { Doc. } \\
\text { no. }\end{array}$ & $5 \%$ \\
\hline 1.20 & 2905 & $\begin{array}{l}\text { Government Draft Act } \\
\text { amending the Act on } \\
\text { Farmers' Health Insurance } \\
\text { Contributions }\end{array}$ & 1.20 & 2905 & $\begin{array}{l}\text { Government Draft Act } \\
\text { amending the Act on } \\
\text { Farmers' Health Insurance } \\
\text { Contributions }\end{array}$ \\
\hline 1.10 & 2968 & $\begin{array}{l}\text { Deputies' Draft Act } \\
\text { amending the Act on } \\
\text { Agricultural and Forestry } \\
\text { Land Protection }\end{array}$ & 1.10 & 2968 & $\begin{array}{l}\text { Deputies' Draft Act } \\
\text { amending the Act on } \\
\text { Agricultural and Forestry } \\
\text { Land Protection }\end{array}$ \\
\hline 1.10 & 2995 & $\begin{array}{l}\text { Deputies' Draft Act - } \\
\text { the Law on Genetically } \\
\text { Modified Organisms }\end{array}$ & 1.10 & 2995 & $\begin{array}{l}\text { Deputies' Draft Act - } \\
\text { the Law on Genetically } \\
\text { Modified Organisms }\end{array}$ \\
\hline 1.08 & 2683 & $\begin{array}{l}\text { Government Draft Act } \\
\text { amending the Act on the } \\
\text { Commercial Quality of } \\
\text { Agricultural and Food } \\
\text { Products and the Act on } \\
\text { Food and Nutrition Safety }\end{array}$ & 1.08 & 2683 & $\begin{array}{l}\text { Government Draft Act } \\
\text { amending the Act on the } \\
\text { Commercial Quality of } \\
\text { Agricultural and Food } \\
\text { Products and the Act on } \\
\text { Food and Nutrition Safety }\end{array}$ \\
\hline 1.02 & 2824 & $\begin{array}{l}\text { Government Draft Act - } \\
\text { the Restructuring Law }\end{array}$ & 1.02 & 2824 & $\begin{array}{l}\text { Government Draft Act - } \\
\text { the Restructuring Law }\end{array}$ \\
\hline 1.00 & 2856 & $\begin{array}{l}\text { Government Draft Act } \\
\text { amending the Act on } \\
\text { Special Economic Zones } \\
\text { and Certain Other Acts }\end{array}$ & 1,00 & 2856 & $\begin{array}{l}\text { Government Draft Act } \\
\text { amending the Act on } \\
\text { Special Economic Zones } \\
\text { and Certain Other Acts }\end{array}$ \\
\hline 1.00 & 2606 & $\begin{array}{l}\text { Government Draft Act } \\
\text { on Facilitating Business } \\
\text { Activity }\end{array}$ & & & \\
\hline 0.98 & 2689 & $\begin{array}{l}\text { Deputies' Draft Act } \\
\text { amending the Act on Plant } \\
\text { Protection Products }\end{array}$ & & & \\
\hline 0.96 & 2996 & $\begin{array}{l}\text { Deputies' Draft Act on } \\
\text { Suspending the Repayment } \\
\text { of Certain Loans Taken } \\
\text { Out to Cover the Costs } \\
\text { of Running Agricultural } \\
\text { Holding }\end{array}$ & & & \\
\hline
\end{tabular}




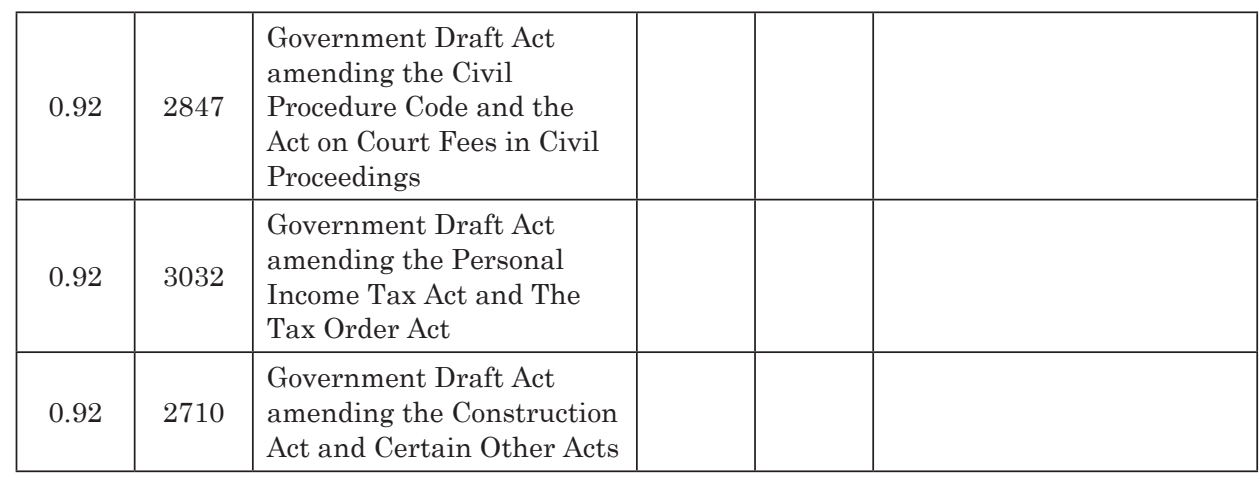

Source: author's own work based on the information of the Sejm.

Table 2 shows the results of the selection of the most significant (according to the IARS) legal acts to undergo ex-post RIA using two limits: $5 \%$ and $10 \%$ of all the analyzed legal acts. They are legal acts, still binding during the assessment period (2016). Their goals and assumptions in terms of the impacts they could exert were initially defined in the justification of their drafts at the beginning of the legislative process. Hence, an ex-post assessment ought to concern the control of the implementation of the goals and the level of the occurrence of the anticipated actual (for example financial, economic and social) results.

\section{CONCLUSIONS}

Today, in the face of the commonly criticized 'legislative inflation' in different areas of the economy, the economic analysis of a law, including the effects of its enactment, is a necessity. The growing experience of a number of countries in applying the ex-ante assessment of regulatory impacts, and the ex-post assessment in particular, may, over time, contribute to developing practical international standards in this respect. In the case of the assessment being conducted by parliamentary services, it enables a broader and substantive parliamentary control of the legislative process initiated by the government and other authorized institutions.

The Index for the Assessment of Regulations' Significance is meant to be an auxiliary tool to the ex-ante assessment and the independent ex-post assessment by parliament. In the latter case, the Index is also to help parliament in selecting legal acts for the medium-term assessment of their effectiveness in real life, being free from political influence, and impartial and substantive, which should contribute to restraining the phenomenon of over-regulating the economy and the market.

The IARS is a measure developed on the basis of the expertise of the staff of parliamentary services and for the purposes of a given parliament. It is also 
meant to enable other analytical work to be performed separately, as commissioned by parliamentary committees or particular deputies, and within the substantive framework defined by them.

Kamilla Marchewka-Bartkowiak

Poznań University of Economics and Business

kamilla.marchewka-bartkowiak@ue.poznan.pl

https://orcid.org/0000-0001-5703-4189

BAS (2015). Methodological assumptions for ex-ante and ex-post analysis. Bureau of Research, Chancellery of the Sejm 2015, working group research - document unpublished (Polish version: Założenia metodologiczne do analizy ex-ante i ex-post, prace zespołu roboczego ds. OSR pod kierunkiem G. Gołębiowskiego).

$\operatorname{COM}(2010) 543$ final. Communication from the Commission to the European Parliament, the Council, the European Economic and Social Committee and the Committee of the Regions, Smart Regulation in the European Union, Brussels, 8.10.2010.

$\operatorname{COM}(2012) 746$ final. Communication from the Commission to the European Parliament, the Council, the European Economic and Social Committee and the Committee of the Regions, EU Regulatory Fitness.

Cooter, R., Ulen, T. (2008). Law and Economics. Pearson Addison Wesley, Boston-San FranciscoNew-York-London-Toronto-Sydney-Tokyo-Singapore-Madrid-Mexico City-Munich-Paris-Cape Town-Hong Kong- Montreal.

ECPRD (2016). Member States' parliamentary practice and organization regarding impact assessment (ex-ante) and evaluation (ex-post). European Parliament, Request 2832.

OECD (2012). Recommendation of the Council on Regulatory Policy and Governance. Paris.

OECD (2015). Government at a Glance 2015. Paris.

Pearson, H. (1997). Origins of Law and Economics. The Economists' New Science of Law Movement 1830-1930. Cambridge: Cambridge University Press.

Posner, R.A. (2003). Economic Analysis of Law. New York: Aspen Publishers.

Rowley, Ch.K. (1989). Public choice and the economic analysis of law, [in:] N. Mercuro (ed.), Law and Economics. Boston: Kluwer Academic Publishers.

\section{THE CONCEPT OF INDEX FOR \\ THE ASSESSMENT OF REGULATIONS' SIGNIFICANCE (IARS) IN REGULATORY IMPACT EVALUATION}

\section{Sum mary}

This article aims to present the concept of the Index for the Assessment of Regulations' Significance as a tool used in parliamentary regulatory impact assessment, with a special focus on expost assessment. The Index is an element of the broadly defined economic analysis of law, which can facilitate a more effective scrutiny of parliamentary lawmaking. The Index also enables the RIA (Regulatory Impact Assessment) to be verified by the act originator at the stage of the ex-ante regulatory impact assessment. Furthermore, the Index can also serve as a tool for conducting an analysis of the overall legislation process employed in parliament over a given period of time, on the basis of the adopted legal and substantive criteria.

Keywords: regulatory impact assessment; ex-post evaluation; index for the assessment of regulations' significance; parliamentary scrutiny; JEL: K1, K4 